


\title{
Arcobacter butzleri strains isolated from different sources display adhesive capacity to epithelial cells in vitro*
}

\author{
Heriberto Fernández, Sandra Flores \& Fernanda Inzunza
}

\begin{abstract}
Background: The genus Arcobacter, belonging to the family Campylobacteraceae, includes polar flagellated, curved or spiral rod shaped bacteria firstly described as Vibrio/Spirillum organisms and later as aerotolerant Campylobacterlike microorganisms. Currently, this genus comprises nine validated species and a candidatus. Among Arcobacter species, Arcobacter butzleri is recognized as a zoonotic agent and the most common species of the genus isolated from environmental water, food and clinical samples.

Recently, this species was considered a serious hazard to human health. However, their pathological properties, potential virulence factors as well as their clinical significance remain uncertain or not completely defined. The aim of this study was to establish the ability of 78 A. butzleri strains isolated from different sources to adhere to HEp- 2 cells in vitro.

Materials, Methods \& Results: All the strains were isolated using first an enrichment medium incubated aerobically at $26^{\circ} \mathrm{C}$ for $48 \mathrm{~h}$. after that, $100 \mu \mathrm{l}$ of the broth were streaked onto Arcobacter selective agar plates and incubated at $26^{\circ} \mathrm{c}$ for $72 \mathrm{~h}$. all the strains were identified phenotypically using standard assays. Definitive identification was achieved using a multiplex polymerase chain reaction. Adhesive capacity was determined infecting hep- 2 cells with the strains under study following scaletsky's et al. protocol, with slight modifications. An adherent Escherichia coli isolated was included as a positive control, whereas uninoculated cell lines were used as negative controls. Adhesion results were expressed as the percentage of hep- 2 cells showing adhering bacteria and the number of bacteria $( \pm \mathrm{sd})$ adhered to cells was determined. Strains were considered as adherent, if at least $20 \%$ of hep- 2 cells showed one ore more adhered bacteria. Adherence was also demonstrated by scanning electronic microscopy. All the strains showed adhesive capacity to HEp-2 cells in vitro. The lowest adhesion percentage (27\%) was observed in a strain isolated from dog feces. In at least one strain per source it was possible to observe $100 \%$ adhesion. The lowest number of adhered bacteria $(1.03 \pm 1.53)$ was observed in a strain isolated from river water and the highest number $(76.6 \pm 5.59)$, in a strain isolated from duck feces.

Discussion: Regardless of their isolation source, the 78 Arcobacter butzleri strains tested in the present study were able to adhere to HEp-2 cells in vitro. This property was demonstrated in different proportions by other authors in strains isolated from environmental, meat and human fecal samples. Electronic scanning microscopy shows curved bacilli adhering to HEp-2 cells forming a microcolony-like arrangement. This may occur in a stepwise mechanism. First, A. butzleri adhere to HEp-2 cells and then, due to their capacity to form biofilms, interbacterial adherence can be expressed. The capacity of $A$. butzleri to form biofilms attaching to stainless steel, copper and glass has been demonstrated in previous studies. Further studies are necessary to elucidate the molecular and cellular mechanisms accounting for this biological property; and hence, its actual role in the colonization of human and animal intestinal epithelium by A. butzleri.
\end{abstract}

Descritores: Arcobacter butzleri, aderência, células HEp-2, fator de virulência.

Keywords: Arcobacter butzleri, adhesion, HEp-2 cells, virulence factor. 


\section{INTRODUCTION}

The genus Arcobacter, belonging to the Family Campylobacteraceae, includes polar flagellated, curved or spiral rod shaped bacteria firstly described as Vibrio/Spirillum organisms and later as aerotolerant Campylobacter-like microorganisms. Currently, the genus Arcobacter comprises the following species: A. cryaerophilus, A. butzleri, A. skirrowii, A. nitrofrigilis, A. cibarius, A. halophilus, A. mytili, A. thereius, A. marinus and "Candidatus A. sulfidicus" $[5,15,17]$. Among these species, only three, A. butzleri, A. cryaerophilus and A. skirrowii have been recognized as zoonotic agents, recovered from man and animals [19]. At present, A. butzleri is considered the most common species of the genus in environmental water, food and clinical samples [12], being ranked as the fourth most common campylobacter organism isolated from human feces in two independent studies performed in Belgium and France [24,27]. However, their pathological properties, potential virulence factors as well as their clinical significance remain uncertain or not completely defined [2,3,22].

Recently, this species was considered a serious hazard to human health by the International Commission on Microbiological Specification for Foods [16]. A. butzleri has been isolated in cases of chronic diarrhea in south areas of Chile [6], environmental waters, mussels, chicken livers, pets and domestic farm animals, including domestic and wild foul $[7,8]$.

Given the growing epidemiological importance of this food-borne emerging enteropathogenic agent, the purpose of this study was to determine the ability of 78 A. butzleri strains isolated from different sources to adhere to epithelial cells in vitro.

\section{MATERIALS AND METHODS}

A total of 78 strains of Arcobacter butzleri were isolated from fecal samples (pelican $[n=10]$, bovine [n=5], duck $[n=5], \operatorname{dog}[n=5]$ and sparrow $[n=3])$, as well as from river water $(n=15)$, chicken giblets $(n=13)$, chicken carcasses $(n=8)$ and mussels $(n=5)$.

All the strains were isolated using as enrichment medium the Arcobacter broth supplemented with amphotericin B $(10 \mathrm{mg} / \mathrm{l})$, cefoperazone (16mg/l), 5-fluorouracil (100 mg/l), novobiocin (32 mg/l) and trimethoprim (64 mg/l) [13] and incubated aerobically at $26^{\circ} \mathrm{C}$ for $48 \mathrm{~h}$. After enrichment, $100 \mu \mathrm{l}$ of the broth were streaked onto Arcobacter selective agar plates and incubated at 26 ${ }^{\circ} \mathrm{C}$ for $72 \mathrm{~h}$. All the strains were identified phenotypically using standard assays [26]. Definitive identification was achieved using the multiplex polymerase chain reaction as previously described for the simultaneous identification of A. butzleri, A. cryaerophilus and A. skirrowii [14].

Adhesive capacity was determined infecting HEp-2 cells with the strains under study following Scaletsky's et al. protocol [25], with slight modifications. In brief: four Leighton tubes containing a coverslip with the HEp-2 cells monolayers were used for each strain. They were inoculated with $1 \mathrm{ml}$ of the bacterial suspensions $\left(10^{6}\right.$ c.f.u) made up in the same medium used for growing HEp-2 cells (RPMI medium supplemented with $10 \%$ fetal calf serum) and incubated at $37{ }^{\circ} \mathrm{C}$ during $3 \mathrm{~h}$, under $5 \%$ $\mathrm{CO}_{2}$. Afterwards, coverslips were washed four times with phosphate-buffered saline $\mathrm{pH}$ 7.4, fixed with methanol, stained with $10 \%$ Giemsa stain and examined under light microscopy $(1,000 \mathrm{X})$. Adhesive capacity was confirmed by scanning electron microscopy (Figure 1).

An adherent Escherichia. coli isolate was included as a positive control, whereas uninoculated cell lines were used as negative controls. Adhesion results were expressed as the percentage of HEp-2 cells showing adhering bacteria and the number of bacteria $( \pm \mathrm{SD})$ adhered to cells was determined. Following the proportion defined for Campylobacter by Lindblom et al. [20], strains were considered as adherent if at least $20 \%$ of HEp-2 cells showed one ore more adhered bacteria. Adherence was also demonstrated by scanning electronic microscopy.

\section{RESULTS}

All the strains showed adhesive capacity to HEp-2 cells in vitro. The lowest adhesion percentage $(27 \%)$ was observed in a strain isolated from dog feces (Table 1). In at least one strain per source it was possible to observe $100 \%$ adhesion (Table 1). The lowest number of adhered bacteria $(1.03 \pm 1.53)$ was observed in a strain isolated from river water, while the highest number $(76.6 \pm 5.59)$ was observed in a strain isolated from duck feces (Table 1). 
Fernandéz, H., Flores, S. \& Inzunza, F. 2010. Arcobacter butzleri Strains Isoleted Form Different Sources Adhesive Capacity to Epithelial Cells in vitro* Acta Scientiae Veterinariae. 38(3): 282-287.

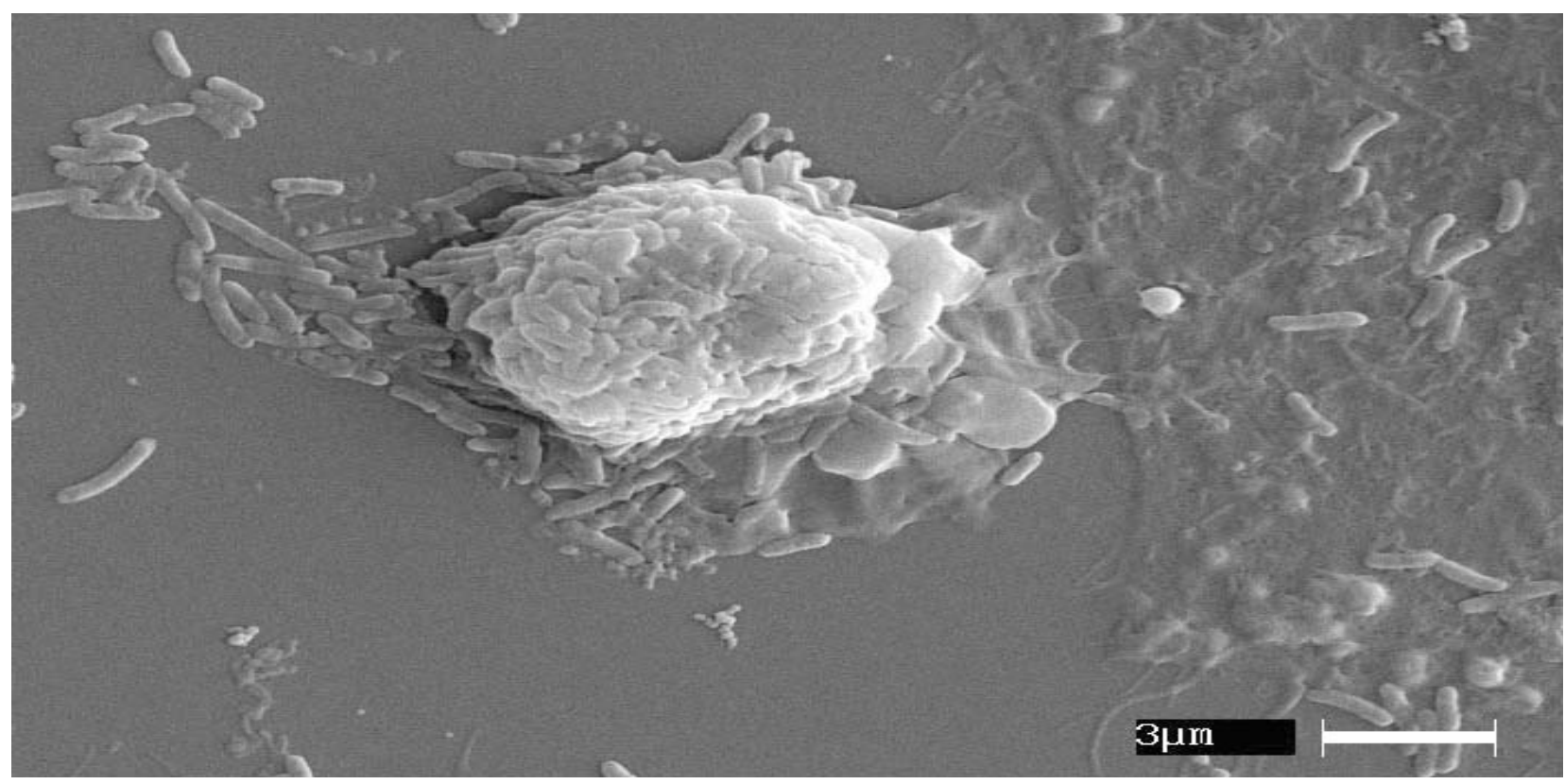

Figure 1. Scaning electronic microphotography showing A. butzleri adhered to HEp-2 cell

\section{train origin}

Iuman feces

elican feces

iovine feces

ruck feces

$\log$ feces

parow feces

iver water

hicken giblets

'hicken carcasses

Tussels

\begin{tabular}{|c|c|c||}
\hline \hline $\begin{array}{c}\text { Number of strains } \\
\text { studied }\end{array}$ & Adhesion $^{\mathbf{1}}$ & Number of adhered bacteria $^{2}$ \\
\hline 3 & $84-100$ & $4.39 \pm 4.66-25.74 \pm 11.61$ \\
\hline 10 & $65-100$ & $1.51 \pm 1.50-13.12 \pm 10.78$ \\
\hline 5 & $99-100$ & $11.45 \pm 7.47-29.6 \pm 11.2$ \\
\hline 5 & $73-100$ & $6.2 \pm 1.64-76.6 \pm 5.59$ \\
\hline 5 & $27-100$ & $2.4 \pm 0.89-30.4 \pm 3.2$ \\
\hline 3 & $48-100$ & $2.6 \pm 1.14-28 \pm 4.47$ \\
\hline 15 & $46-100$ & $1.03 \pm 1.53-44.6 \pm 5.73$ \\
\hline 13 & $66-100$ & $1.11 \pm 1.79-68.8 \pm 6.98$ \\
\hline 8 & $80-100$ & $2.59 \pm 2.39-21.35 \pm 12.29$ \\
\hline 5 & $46-100$ & $5.01 \pm 5.58-23.46 \pm 11.65$ \\
\hline \hline
\end{tabular}

Table 1. Adhesive capacity of Arcobacter butzleri strains isolated from different sources ${ }^{1}$ ranges of the percentages of HEp-2 cells showing adhesive bacteria

${ }^{2}$ ranges of the number of adherent bacteria to HEp- 2 cells

High-power scanning microscopy confirmed the actual adhesion of A. butzleri to HEp-2 cells in vitro showing curved bacilli adhering to HEp-2 cells, giving rise to an arrangement resembling a microcolony (Figure 1).

\section{DISCUSSÃO}

Attachment to inert surfaces and adhesive capacity to epithelial cells are bacterial characteristics associated to environmental persistence and to bacterial pathogenicity, respectively. Both characteristics have been described in some zoonotic food-borne pathogens like Listeria monocytogenes $[10,21]$ and Yersinia enterocolitica [10,23]. In the case of Arcobacter butzleri, a few studies on attachment to inert surfaces $[1,4,18]$ and in vitro adhesion to epithelial cells $[3,11,22,28,29]$ are available. 
In this study, we determined the ability of $A$. butzleri strains isolated from fecal samples of different animals, as well as from chicken meat (giblets and carcasses), mussels and river water to adhere to HEp2 cells. All the strains showed adhesive capacity. The adhesion percentages varied from 27 to $100 \%$ and the number of adhered bacteria per cell, from $1.03 \pm$ 1.53 to $76.6 \pm 5.59$. Previous studies on environmental strains $[3,22]$ reported that $1 / 171 / 18$ and of the strains respectively, were able to adhere to epithelial cell lines. Higher adhesion capacities were observed in a study done in Mexico, where 34 of 60 strains isolated from retail meats were adherent [29]. In Belgium, Vandenberg et al. [28] showed that all 12 A. butzleri strains isolated from human stool samples were able to adhere to HEp-2 cells; and Hoa et al. [11] reported that all 8 strains of four Arcocabter species tested, adhered to human Caco-2 and porcine IPI-2I cells.

Electronic scanning microscopy (Figure 1) shows curved bacilli adhering to HEp-2 cells forming an arrangement resembling a microcolony. This phenomenon may occur in a stepwise mechanism. First, A. butzleri adhere to HEp-2 cells and then, due to their capacity to form biofilms, interbacterial adherence can be expressed. Previous studies have demonstrated the capacity of A. butzleri to form biofilms while attaching to stainless steel, copper and glass $[1,4,18]$.

In synthesis, we have shown a significant adhesive capacity to epithelial cells for Arcobacter butzleri strains from different origins. Further studies are necessary to elucidate the molecular and cellular mechanisms accounting for this biological property; and hence, its actual role in the colonization of human and animal intestinal epithelium by A. butzleri.

\section{CONCLUSION}

Regardless of their isolation source, the 78 Arcobacter butzleri strains tested in the present study were able to adhere to HEp-2 cells in vitro.

Acknowledgments. Thanks are due to Dr. Hans G. Richter (Department of Physiology, Development \& Neuroscience, University of Cambridge and Department of Anatomy, Histology and Pathology, Universidad Austral de Chile) for their advices and critical review. This work received financial support from Grants FONDECYT 1030245 and DID UACh S-2004-01 and SE-1-2009.

\section{REFERENCES}

[1] Assanta M.A., Roy D., Lemay M.J. \& Monpetit D. 2002. Attachment of Arcobacter butzleri, a new waterborne pathogen, to water distribution pipe surfaces. Journal of Food Protection. 65(8): 1240-1247.

[2] Bücker R., Troeger H., Kleer J., Fromm M. \& Schulzke J.-D. 2009. Arcobacter butzleri indices barrier dysfunction in intestinal HT-29/B6 cells. The Journal of Infectious Diseases. 200(5): 756-764.

[3] Carbone M., Maugeri T.L., Giannone M., Gugliandolo C., Midiri A. \& Fera M.T. 2003. Adherence of environmental Arcobacter butzleri and Vibrio spp. isolates to epithelial cells in vitro. Food Microbiology. 20(5): 611-616.

[4] Cervenka L., Kristlova J., Peskova I., Vytrasova J., Pejchalova M. \& Brozkova I. 2008. Persistence of Arcobacter butzleri CCUG 30484 on plastic, stainless steel and glass surfaces. Brazilian Journal of Microbiology. 39(3): 517-520.

[5] Collado L., Cleenwerck I., Van Trappen S., De Vos P. \& Figueras M.J. 2009. Arcobacter mytili sp. nov., an indoxyl acetate hydrolysis negative bacterium isolated from mussels. International Journal of Systematic and Evolutionary Microbiology. 59(6): 1391-1396.

[6] Fernández H., Krause S. \& Villanueva M.P. 2004. Arcobacter butzleri an emerging enteropathogen: communication of two cases with chronic diarrhea. Brazilian Journal of Microbiology. 35(3): 216-218.

[7] Fernández H., Otth L., Wilson M., Rodríguez R., Saldivia C. \& Barría P. 2001. Occurrence of Arcobacter sp. in river water, mussels and commercial chicken livers in Southern Chile. International Journal of Medical Microbiology. 291(Suppl 31 ): 140.

[8] Fernández H., Vera F. \& Villanueva M.P. 2007. Arcobacter and Campylobacter species in birds and mammals from Southern Chile. Archivos de Medicina Veterinaria. 39(2): 163-165.

[9] Herald P.A. \& Zottola E.A. 1988. Scanning electron microscopic examination of Yersinia enterocolitica attached to stainless steel at selected temperatures and pH values. Journal of Food Protection. 51(6): 445-448.

[10] Herald P.A. \& Zottola E.A. 1988. Attachment of Listeria monocytogenes to stainless steel surfaces at various temperatures and $\mathrm{pH}$ values. Journal of Food Science. 53(5): 1549-1552. 
Fernandéz, H., Flores, S. \& Inzunza, F. 2010. Arcobacter butzleri Strains Isoleted Form Different Sources Adhesive Capacity to Epithelial Cells in vitro* Acta Scientiae Veterinariae. 38(3): 282-287.

[11] Meyer D.H., Bunduki M., Beliveau C.M. \& Donnely C.W. 1992. Differences in invasion and adherence of Listeria monocytogenes with mammalian gut cells. Food Microbiology. 9 (2): 115-126.

[12] Ho H.T.K., Lipman L. J.\& Gaastra W. 2006. Arcobacter, what is known and unknown about a potential foodborne zoonotic agent. Veterinary Microbiology. 115(1): 1-13.

[13] Houf K., Devriese L.A., De Zutter L., Van Hoof J. \& Vandamme P. 2001. Development of a new protocol for the isolation and quantification of Arcobacter species from poultry products. International Journal of Food Microbiology. 71(2): 189-196.

[14] Houf K., Tutenel A., De Zutter L., Van Hoof J. \& Vandamme P. 2000. Development of a multiplex PCR assay for the simultaneous detection and identification of Arcobacter butzleri, Arcobacter cryaerophilus and Arcobacter skirrowii. FEMS Microbiology Letters. 193(1): 89-94.

[15] Houf K., On S., Coenye T., Debruyne L., De Smet S. \& Vandamme P. 2009. Arcobacter thereius sp. nov., isolated from pigs and ducks. International Journal of Systematic and Evolutionary Microbiology. 59(10): 2599-2604.

[16] International Commission on Microbiological Specifications for Foods (ICMSF). 2002. Microorganisms in Foods 7. Microbiological Testing in Food Safety Management. New York: Kluwer Academic/Plenum Publishers, pp.275-171.

[17] Kim H.M., Hwang C.Y. \& Cho B.C. 2010. Arcobacter marinus sp. nov. International Journal of Systematic and Evolutionary Microbiology. 60: 531-536.

[18] Kjeldgaard J., Jorgensen K. \& Ingmer H. 2009. Growth and survival at chiller temperatures of Arcobacter butzleri. International Journal of Food Microbiology. 131(2-3): 256-259.

[19] Lehner A., Tasara T. \& Stephan R. 2005. Relevant aspects of Arcobacter spp. as potential foodborne pathogen. International Journal of Food Microbiology. 102(2): 127-135.

[20] Lindblom C.B, Cervantes L.E, Sjögren E, Kaijser B. \& Ruiz-Palacios G.M. 1989. Adherence, enterotoxigenicity, invasiveness and serogroup characteristics for Campylobacter jejuni and Campylobacter coli strains from adult patients with acute enterocolitis. In: Ruiz-Palacios GM, Calva E, Ruiz-Palacios BR (Eds). Campylobacter V. Proceedings of the Fifth International Workshop on Campylobacter infections (Mexico City, México). pp.199-201.

[21] Meyer D.H., Bunduki M., Beliveau C.M. \& Donnely C.W. 1992. Differences in invasion and adherence of Listeria monocytogenes with mammalian gut cells. Food Microbiology. 9 (2): 115-126.

[22] Musmanno R.A., Russi M., Lior H. \& Figura N. 1997. In vitro virulence factors of Arcobacter butzleri strains isolated from superficial water samples. New Microbiologica. 20: 63-68.

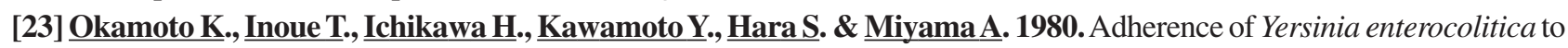
mammalian epithelial cell lines. Microbiology and Immunology. 24(11): 1013-1022.

[24] Prouzet-Mauléon V., Labadi L., Bouges N., Ménard N. \& Mégraud F. 2006. Arcobacter butzleri: Underestimated Enteropathogen. Emerging Infectious Diseases. 12(2): 307-309.

[25] Scaletsky I.C.A., Silva M.L.M. \& Trabulsi L.R. 1984. Distinctive patterns of adherence of anteropathogenic Escherichia coli to HeLa Cells. Infection and Immunity. 45(2): 534-536.

[26] Vandamme P., Dewhirst F.E., Paster B.J. \& On S.L.W. 2005. Genus II. Arcobacter. In: Brenner D.J., Kreig N.P., Staley J.T. \& Garrity G.M. (Eds.). Bergey's Manual of Systematic Bacteriology. v.2. 2nd edn. New York: Springer, pp.1161-1165.

[27] Vandenberg O., Dediste A., Houf K., Ibekwem S., Souayah H., Cadranel S., Douat N., Zissis G., Butzler J.-P. \& Vandamme P. 2004. Arcobacter species in humans. Emerging and Infectious Diseases. 10(10): 1863-1867.

[28] Vandenberg O., Fernández H., Houf K., Dediste A., Zissis G. \& Butzler J.-P. 2005. Virulence factors of Arcopbacter species isolated from humans with and without clinical symptoms. In: 13th International Workshop on Campylobacter, Helicobacter and related Organisms. Gold Coast: Griffith University Publications, p.99.

[29] Villarruel A., Garay L.E., Zepeda H.M., Aparicio G., Castillo A., Ascencio F. \& Torres-Vitela M. 2003. Adherence and invasiveness of Arcobacter butzleri. International Journal of Medical Microbiology. 293(Suppl 35): 78. 